\title{
Culture: What to Teach and How to Teach It in an EFL Class
}

\author{
CHEN Yan-hui \\ Shanghai Institute of Technology, Shanghai, China
}

\begin{abstract}
This paper discusses the question of the teaching of culture in an EFL (English as a Foreign Language) class. With the open door policy, an increasing number of people in China are learning English or some other language for various purposes. However, they often experience the frustration of failure in communication with foreigners which can sour relationships or business due to their ignorance of the target culture associated with the language they are learning or have learned. Therefore, teaching culture in foreign language classes and learning a second culture while learning a second language have become new slogans, or to be exact, new tasks in the field of English language teaching in China. But how to teach and what to teach remain problematic. The author holds that "central code” of a culture, i.e., people's way of life should be the focus in EFL teaching. Then choosing appropriate and authentic material containing aspects of culture is of great importance. Greater importance should be attached to mass media and multimedia materials and approaches. At the same time, attention should be paid to the cultural behaviour or belief of EFL teachers so as to make more effective teaching.
\end{abstract}

Keywords: culture, EFL, teaching, authentic materials

\section{Introduction}

The linguist Robert Lado defined the goal of learning a foreign language as "the ability to use it, understanding its meanings and connotations in terms of the target language and culture, and the ability to understand the speech and writing of natives of the target culture in terms of their meanings as well as their great ideas and achievements” (Lado, 1964, p. 25). This definition, he has argued, excludes the necessity of a language learner performing like a native speaker; on the other hand, it includes the need to understand what a native speaker means when he/she says that they acted in a particular way and it also includes the need to know what interpretation the native speaker will make when he/she is told that someone acted in a particular way.

Much of the interest in foreign language teaching has long focused on the system of language itself, on the psycholinguistic aspects of learning and acquisition, and on teaching techniques rather than on content. Lado's goal has pedagogic cultural implications that force us to examine different contexts in which the learning and use of the foreign language take place and the social and cultural forces at play. The goal also brings the teaching of culture in the classroom from the background to the foreground so as to develop the learners' cultural awareness along with their foreign/second language awareness.

The significance of the crucial dependence of linguistic skills on cultural premises has been fashionably proclaimed in China in recent years. However, what and how to impart the cultural dimension of a non-native 
language in a class is still a great problem requiring more discussion and practice.

\section{“Culture Shock" and the "Central Code" of a Culture}

The discussion of "culture shock", a term popular in social science and cross-cultural communication studies as well as in the EFL/ESL teaching field, might help us to know more about what we should teach in class in order to reduce culture shock. Culture shock refers to a psychotic state of distress that people get into when they move from one culture to another. E. T. Hall (1959) defined culture shock as the removal or distortion of many of the familiar cues of one's environment and their substitution by other cues or codes that are strange. These people, in spite of the fact that they can use the target language fluently, still feel that facing a strange culture is, "bewildering, confusing, depressing, anxiety-provoking, humiliating, embarrassing and generally stressful in nature” (Bochner, 1982, p. 171). It is believed that culture shock is universal and virtually inevitable. Experiencing culture shock does not mean that an individual is inflexible or unaccepted, but that his cultural knowledge is insufficient and his attitude towards an unfamiliar culture is not well-established.

How to reduce culture shock has generated a heated discussion. According to Brislin (1979), there are five types of programmes to alleviate culture shock: self-awareness training in which people learn about the cultural bases of their own behaviour; cognitive training in which people are given information about another culture before direct contact with it; attribute training which features the characteristic explanations of social behaviour from another culture's standpoint, behaviour modification, and experimental learning exercises. Among these, cognitive training of a second culture is what we EFL teachers can and should give to the language class.

Culture in relation to language teaching is mainly a way of life. So what we should teach in EFL classes is simply a foreign way of life related to the target language. However, when we say a people's way of life, we are, to some extent, abstracting a description from concrete data. In the activity of teaching, we have, for example, to schematise this way of life into certain categories in which, presumably, there are going to be important aspects of the way foreign people live, whether it be like ours or different from ours. The problem is when teachers are required to input cultural knowledge into a language class, they often reply: "I have brought culture into my class already”. Here what they have mentioned is something quite superficial, just some romanticised local colour of a culture, such as the fact that English people always sit on chairs round a table to eat a breakfast consisting of cornflakes, toast, and marmalade; or English are all football lovers. It is not necessary to teach students to be bicultural, yet this kind of teaching by adding some uncertain cultural colour is not sufficient and can even be misleading. What we teach in the classroom should be something neither too abstract nor too concrete, but should focus on "the central code" (Nostrand, 1989, p. 51) of a culture. This central code consists not only of customs and proprieties, as Nostrand said, “it involves above all the culture's 'ground meaning': its system of major values, habitual patterns of thought, and certain prevalent assumptions about human nature and society which the foreigners should be prepared to encounter" (p. 52). To be specific, the central code of the foreign culture in teaching activity, may fall into four categories: developing a great awareness of a broader knowledge about the target culture; acquiring a command of the etiquette of the target culture; understanding differences between the target culture and the students' culture; and understanding the values of the target culture (quoted in Prodromou, 1992, p. 4). 


\section{Foreign Culture in EFL Materials}

Choosing relevant material containing cultural aspects of the target language is of first and essential importance. Marckwardt et al. (1953, pp. 1217-1218) drew up a set of general but important questions teachers should take into consideration with regard to the content of material, such as: Does the material focus upon characteristic and significant aspects or the central code of the foreign culture? Can the material be so organised that students will leave the course with a fairly clear idea of some salient aspects of the foreign culture? In using this material, can important traits or themes be compared or contrasted with typically foreign way of behaviour? And can this be done in a manner leading to a better understanding of the foreign life? Are the students stimulated to search for historical or other explanations for values which differ from his own?

The chosen materials, he stated, can be arranged into four categories: (1) elementary material presenting cultural information in a disorganised and unrelated fashion; (2) cultural miscellanies with a preoccupation with the picturesque and trivially bizarre; (3) comprehensive cultural histories with a propagandistic slant; and (4) literary texts that were not intended to elucidate culture but to develop skills in criticism.

There are quite a lot of textbooks of cultural background with, for example, photographs of the House of Parliament, maps of the London underground system, and illustrations of the criminal justice system and social structure. Cultural background knowledge is also invoked indirectly in some reading materials, such as L. G. Alexander's New Concept English, a well-received supplementary textbook for high school and college students in China. This kind of material contains extracts from newspaper, letters, specialist articles on pop music, sports, fashion, and film/TV. These textbooks have been widely used over the years, but some of them are greatly criticised for that they are believed to have projected some kind of Anglo-centric, Americanist or male-dominated, middle-class Utopian images. Some course-books convey some culture knowledge that may entice learners to gain some over-generalised information. For example, in some textbooks, London is often described as a busy, noisy, but interesting city; Brighton, a cleaner tourist centre; Stockport, an industrial and dirty place while "people there are very friendly"; “These characterisations”, commented Clarke (1990), "are acceptable only if we see groups as uniform rather than heterogeneous collections of individuals” (p. 39). Some other cultural knowledge, for example, about the criminal justice system contains information very unfamiliar even to native speakers. Some situational dialogues in the textbook "lack communicative intent” (Scott, 1981) and "invariably have very little transfer value to genuine real-life situations” (Taborn, 1983). “...They are unreal, impersonal, and inactive. They are pure fantasy. The material we are teaching may be rubbish” (Prodromou, 1988). Materials which focus on topics like football, fashion, etc., actually do not require knowledge of any particular culture but simply some acquaintance with Westernised cosmopolitan culture which is quite easy for language learners to encounter by themselves on television all over the world (Brown, 1953).

Generalisations are inevitable in teaching a foreign culture and it is impractical to ask that all aspects of a perpetually varying society should be shown in the textbooks. However, many significant features of British or American life go unpresented or misrepresented. Race, gender, and other cultural issues are considerably neglected. Students feel distant and therefore there is no basis for empathy, such as possible shared problems and attitudes, and at worst, they may "suffer from misinformation and ignorance leading to prejudice in their relationship with a culture they meet partly, or uniquely, in the illustrations and texts of a TESL textbook" (Clarke, 1990, p. 30). 
It is difficult and also impractical to compile an ideal textbook catering for all the language learners of various cultural backgrounds. It has proved useful for EFL teachers to evaluate the present texts and make the best use of some relatively good materials in hand. As a learner of English who has never resided in the target language culture, gaining some superficial second hand knowledge of such things as British or American geography, customs, and festivals is still quite beneficial. Writers of the textbooks mentioned above have endeavoured to put what they have considered important aspects of culture in a suitable way, but also consciously or unconsciously transmit the views, values, beliefs, attitude, and feelings of their own English-speaking society, which can also help us to know that culture from various angles. However, in order to gain maximum access to the target culture with real-life situations and natural life-like communication, it is necessary to select supplementary cultural materials from available authentic sources.

\section{Using Authentic Materials to Teach Culture}

The term "authentic" has been used as a reaction against the prefabricated artificial language of textbooks and instructional dialogues. Philip Riley defined an authentic document as: (1) one which has never been produced for language learning or language teaching purposes; and (2) one which has been produced in a real communication situation. "Authentic texts", as Kramsch (1993) stated, "require participants to respond with behaviours that are socially appropriate to the setting, the status of the interlocutors, the purpose, key, genre, and instrumentality of exchange, and the norms of interaction agreed upon by the native speaker” (p. 178). Readers are required to adopt the communicative reading strategies of native speakers, such as skimming and scanning for information desired, finding clues from the context, and recognising the author's intention.

Mass media, such as film, novels, and especially newspapers and magazines, are also considered an insightful means for teaching culture, for they reflect people's way of life in terms of variety, contemporaneity, and authenticity. Students in an EFL setting will spontaneously ask questions about puzzling aspects of society and life as reflected in the film or magazine. This material is by no means easy to interpret because there is so much central inference and it requires deep familiarity with and comprehensive exegeses of the culture in question. Therefore, "all such material should be selected with an eye to the subculture diversity of the target community", i.e., its socio-economic, religious, regional, generation, and ethnic sub-culture, so that learners do not end up thinking of the target culture as one uniform set of experience and values (Loveday, 1982, p. 55). Teachers can also pick up some materials pertaining to some aspects of culture revealed in newspapers or magazines and to the discussions of certain questions that might elucidate Western patterns of behaviour. For example, as Blatchford (1986, p. 131) pointed out that while reading the front pages we can talk about the questions like: What is worthy of the front page? What does the editor feel will most tempt a reader to buy and his paper? What are the events of concern to a reader's life? What cultural mores do crimes, war, danger, or threat transgress to make stories newsworthy?

Besides, audio-visual media materials and approaches, so different from the traditional chalk and blackboard method, are widely welcome due to their vivid presentation of both language and cultural knowledge based on authentic circumstances. Educationists have reacted with much imagination and enthusiasm in exploiting the capabilities of modern technology. Some teachers believe that using media in the teaching of $\mathrm{EFL/ESL} \mathrm{in} \mathrm{the} \mathrm{classroom} \mathrm{is} \mathrm{certain} \mathrm{to} \mathrm{bring} \mathrm{about} \mathrm{a} \mathrm{superior} \mathrm{result.} \mathrm{It} \mathrm{helps} \mathrm{to} \mathrm{simplify} \mathrm{the} \mathrm{teaching/learning}$ 
process and can help to perfect it. Moreover, it can bring in cultural input in a clear and realistic way as compared with traditional, media-free instruction.

\section{Pitfalls and Conclusion}

In the teaching of culture in China, in my opinion, there exist some pitfalls through which EFL teachers especially in China have been diverted from the central task. For example, some teachers feel puzzled about what to teach; they therefore pour facts and figures concerning the economy and sociology of the target culture into the classroom. When students are bombarded with a great amount of sociological information, they may feel bored with all those dull statistical tables, and thus lose interest in the culture class. And it is widely accepted that the cultural knowledge to be transmitted in an EFL classroom is only available to a native of that culture. In China, we often invite a native teacher to offer such courses like cultural background. We take it for granted that it is his/her task to import their culture to students since we are not familiar with that culture but they experience it and are able to accurately express it. We should realise that it is not necessarily the case that only native speakers should teach culture. A non-native speaker might in some way be more conscious of deficiencies in his/her students' grasp of the target culture because of his/her intimate knowledge of their cultural domain. Some native teachers often tend to take their way of life for granted and therefore find it a bit difficult to present that essential background information. Familiarising with the contrasts between both the L1 and EFL may make for more effective teaching. Finally, we should pay certain attention to the cultural behaviour and belief of EFL teachers. There are some teachers who hold that ours is the natural way of life while the ways of others are strange and unacceptable. The worst thing is that they will naturally bring this kind of cultural prejudice into the class, which influences the students and even leads to contempt and hostility towards the foreign culture, thus greatly affecting students' attitudes towards the foreign language and learning.

It is vital for EFL teachers to remember that language is not operated in a social void, rather it is a social creation, and communication is a social act. Students' linguistic competence cannot be possibly developed fully without the aid of cultural competence. On the other hand, teaching culture entails more than familiarisation with different social, political, and religious circumstances. It also involves the acquisition of communicative behaviour that is culture-specific.

\section{References}

Blatchford, C. (1986). Newspapers for teaching ESOL with a cultural focus. J. M. Valdes (Ed.), Culture bound. Cambridge: CUP. Bochner, S. (Ed.). (1982). Culture in contact. Oxford: Pergamon Press.

Brislin, R. W. (1979). Oriental programs for cross-cultural preparation. In A. J. Marsella, R. G. Tharp, and T. J. Ciborowski (Eds.), Perspectives on cross-cultural psychology. New York: Academic Press.

Brown, R., Englekirk, J., French, D., Johnston, M., Lange, V., Marckwardt, A., ... Wheeler, B. (1953). Developing cultural understanding through foreign language study: A report of the MLA interdisciplinary seminar in language and culture. PMLA, 68(5), 1196.

Clarke, J. M. (1990). Stereotyping in TESOL. In B. Harrison (Ed.), Culture and the language classroom. London and Basingstoke: Modern English Publications.

Hall, E. T. (1959). The silent language. New York: Doubleday, Garden City.

Kramsch, C. (1993). Context and culture in language teaching. Oxford and New York: OUP.

Lado, R. (1964). Language teaching, a scientific approach. New York: McGraw-Hill, Inc.

Loveday, L. (1982). The sociallinguistic of learning and using a non-native language. Oxford and New York: Pergamon Press. 
Nostrand, H. L. (1989). Authentic texts—Cultural authenticity: An editorial. Modern Language Journal, 73(1), 49-52. Prodromou, L. (1988). English as cultural action. ELT Journal, 41(2), 73-83.

Prodromou, L. (1992). Cross-cultural factors in language learning. ELT Journal, 46(1), 39-50.

Scott, R. (1981). Speaking. In K. Johnson and K. Morrow (Eds.), Communication in the classroom. London: Longman. Taborn, S. (1983). The transitional dialogue: Misjudged, misused, misunderstood. ELT Journal, 37(3), 207-213. 